\title{
Recent Books on Malayan Independence
}

\author{
S.R. Joey Long \\ National University of Singapore \\ hislsrj@nus.edu.sg
}

Leon Comber, Templer and the Road to Malayan Independence. The Man and His Time. Singapore: ISEAS, 2015, xxvi + 240 pp. ISBN 9789814620109. Price: USD 29.90 (paperback).

Kumar Ramakrishna, "Original Sin"? Revising the Revisionist Critique of the 1963 Operation Coldstore in Singapore. Singapore: ISEAS, 2015, vii +168 . ISBN 9789814620437. Price: USD 25.90 (paperback).

The British had their hands full managing political developments in Southeast Asia after World War II. Across Malaya and Singapore, the war let loose various sociopolitical forces, opposed to the return of the status quo ante bellum. Personalities in these lands-some more vehement than others-campaigned for change. A number resorted to armed conflict. Seeking to preserve their interests, British officials dealt with these challenges in diverse ways. They responded to violence with violence. They promulgated draconian legislation to repress those deemed hostile to British interests. They initiated constitutional reform and cultivated local allies to effect a peaceful transfer of power. In undertaking all of these measures, British policymakers sought to assert control over developments and create postcolonial outcomes they would accept.

What eventuated, though, did not always adhere to British aspirations. Southeast Asian politicians and revolutionaries had objectives they wanted to pursue, and were unrelenting in applying pressure on British officials to accede to their ambitions. They also turned on their local opponents. Communist insurgents applied brutal force against perceived informants and class enemies. Noncommunist Malayan and Singaporean politicians also employed the repressive political and security instruments they inherited from the British against their local adversaries. Although historians have examined these matters in some detail, much can still be gleaned from new approaches and new source materials about the postwar histories of Malaya and Singapore. The two books under review will enliven scholarly debates of those subjects.

(C) S.R. JOEY LONG, 2017 | DOI: 10.1163/22134379-17302008

This is an open access article distributed under the terms of the prevailing CC-BY-NC license at the time of publication. 
Leon Comber employs a biographical approach to assess the impact of British policies toward postwar Malaya. His work focuses on Gerald Templer. Appointed High Commissioner and Director of Operations in 1952, Templer was commissioned to perform two key tasks: manage the political restiveness in Malaya and quell the communist insurgency that had broken out in 1948. Through Templer, the British government sought to further the cause of political change in Malaya. Britain's preference was for friendly, if not nonadversarial, Malayan leaders to eventually assume power and sustain the selfgoverning state's association with the British Commonwealth. In Comber's narrative, Templer achieved limited success in Malaya.

Comber challenges the views of scholars who contend that Templer saved Malaya from communism, and paved the way for the territory to achieve selfgovernment and eventual independence. He attributes the defeat of the communists to the program Templer's predecessor, Harold Briggs, orchestrated. Briggs had directed his forces to forcibly move hundreds of thousands of communist sympathizers and victims of communist harassment to well-defended hamlets. The effort isolated and starved the insurgents of local support. Templer arrived in Malaya as the Briggs plan was having its intended effect. If Templer played any part in subjugating the insurgents, it was in intensifying the implementation of the Briggs plan. Even so, as Comber observes, Templer's ruthlessness alienated many. He imposed food restrictions against uncooperative Malayans in Tanjong Malim. He also had houses razed in Permatang Tinggi. Templer did not win a lot of hearts and minds for the British cause. When he left Malaya in 1954, the insurgency remained active for another six years before it was finally quelled.

While Templer's anticommunist operations achieved limited success, his foray into other areas of Malayan society also tended to be unenlightened. Comber highlights episodes to make his case. He notes that Templer did not do much to promote racial ties, championing instead discriminatory citizenship and education policies. Templer upheld a judicial system that favored Europeans over Malayans. He also had a jaundiced view of local politicians, resisting the swifter devolution of power to Malayans. His condescending attitude and gruff manners provoked Malayan politicians, turning them against British policies.

If the British government wanted to promote an orderly transfer of power and maintain cordial postcolonial Britain-Malaya relations, Templer did not seem to be the right person to advance that cause. The high commissioner's shortcomings stemmed not from a lack of resolve or lethargy. Rather, Comber faults Templer for being out of touch with Malayan history and aspirations, championing policies that were ill-suited for the political and social context of 
the times. His abrasiveness and spitefulness also alienated and offended many. Comber suggests that Malaya's advance toward self-government would have been smoother had the colonial secretary appointed an official who operated with more tact and diplomacy.

With this book, then, Comber makes a notable contribution to the historiography of the Templer administration in Malaya. His views of Templer are clear. They go against those who praise Templer for turning the tide against the communists and furthering self-government in Malaya. Mining a rich array of archival and published materials, Comber provides admirable balance and persuasive assessments of not only Templer's operational shortcomings, but also the latter's counterproductive sociopolitical policies. In his portrayal, Templer comes out looking less heroic than the image depicted in the conventional historiography. Anyone studying the Templer years in Malayan history will have to contend with Comber's contentions. He has crafted a thoughtful and impressively researched work that will be of interest to students of Southeast Asian history and empire.

Despite its many virtues, the book would have profited from an elaboration of aspects of Templer's life. A more intimate discussion of Templer's upbringing, racial opinions, ideological worldview, and attitude toward empire would have helped readers better understand the official. How did his experiences in Mesopotamia, Persia, Egypt, Palestine, North Africa, and Germany shape his approach to conflict and government? Did the injuries that Templer suffer in Italy change his personality? Weaving those details into the narrative would have added new layers of understanding of Templer's mindset and approach to developments in Malaya. As Comber compellingly tells it, Templer did bring a lot of baggage with him when he was deployed to Malaya.

While Comber holds a dim view of British excesses in Malaya, Kumar Ramakrishna shows enthusiasm for harsh crackdowns on communists in Singapore. Ramakrishna casts the city-state as one of the active sites in Southeast Asia for communist subversion during the 1950s and 1960s. He writes that more than most British officials, and certainly more than what he terms the "Alternates" (a group of revisionist historians, political scientists, and exdetainees who has been writing about the subject), the Lee Kuan Yew government profoundly understood communist machinations and the subversives' capacity to undermine Singapore's sociopolitical order. Ramakrishna accordingly writes that security officials, at the direction of Singaporean, Malayan, and British leaders, appropriately launched Operation Coldstore in 1963-a counter-subversion raid that detained without the need for trials more than one hundred subversives. The operation destroyed the communist movement, brought political stability, and enabled Singapore to develop rapidly. 
In crafting his narrative, Ramakrishna seeks to respond to recent works on the subject. Underpinned mainly by declassified British and Australian archival records, these studies challenge the scale of the communist threat to the citystate. They argue that the Lee government overstated the menace of communism. Labelling its political adversaries as communists, the Lee administration opportunistically incarcerated them. According to the revisionists, the 1963 arrests decimated activists, politicians, and unionists whose only crime was a desire for more democratic freedoms and labor rights in Singapore. These progressives looked poised to politically challenge Lee's party at the polls. Operation Coldstore ensured they were not able to do so.

Ramakrishna contests that narrative, and goes to significant lengths to acquit Lee and his allies of political skullduggery. He details the theory of communism, highlighting the ploys instituted by communists to assume power. He then narrates the history of the Malayan Communist Party and the seditious intent of the communist united front in Singapore. He maintains that the activists read Marxist-Leninist and Maoist theory, and relentlessly sought to put theory into praxis. He cites the activities of and statements made by prominent unionist and politician Lim Chin Siong over the course of his public and political life, averring that this leader of the communist tiger did not change his stripes. He describes Lee Kuan Yew's hostile encounters with communists and communist sympathizers in his political party-the Singaporean leader learning from those experiences to never give the subversives an inch. He then employs that understanding, and an array of declassified and still-classified sources to defend the conventional rendering of Operation Coldstore-a security operation mounted by concerned and wised-up politicians not to save their political hides but to rescue Singapore from communism. He adds that the subversives were likely to provoke communal tensions and destabilize Malaya and Singapore to achieve their communist objectives if they were left unmolested. They accordingly had to be stopped. Finally, having disproved revisionism, Ramakrishna defends the veracity and virtues of the official political narrative. He argues that Singaporean school textbooks, while accommodating more cultural and social historical viewpoints, should continue to enlist the conventional political narrative that he defends to advance the city-state's nationbuilding efforts.

This is an admirable study of Singapore's postwar history. Ramakrishna's book is significant because it brings into sharp focus the arrival of the history wars onto Singapore's shores. Detailed in the volume are the brickbats and heated arguments among scholars and historical figures over the interpretations of Singaporean history. Countering those who challenge the conventional narrative, Ramakrishna's book will undoubtedly enliven the debate. 
Scholars curious about the records still tucked away in government repositories will also find the work to be informative. Ramakrishna cites a series of files that, if declassified for research, will appeal to scholars of the history of the Malayan Communist Party, security operations, and Singapore during the 1950s and 196os. Finally, readers looking to further understand the Lee Kuan Yew government's approach to politics and security will find the book instructive. Ramakrishna develops in significant detail Lee's and his cabinet's expansive view of security. His narrative shows that Singapore's domestic security agency functioned essentially like a pre-crime unit, nipping problems in the bud. He explains why, and his views offer insight into the world views of Lee and his allies.

As with Comber's, there are missed opportunities in Ramakrishna's book. The babel of terms used to label figures or groups could have been better specified. If accepted uncritically, labels such as 'extremist', 'left wing', and 'pro-Communist' tend to stigmatize, block historical empathy, and potentially misinform. What ideas, for example, did the so-called left wingers or procommunists actually embrace, and why? Did those ideas differ from communism? By addressing those questions, Ramakrishna could have helped readers better understand the personalities that he writes about - their discontent, their needs, and their aspirations.

Ramakrishna could likewise have better developed the historical context in which the personalities lived. Not fully elaborated in the narrative are the history of the anti-British movement, socioeconomic discontent in Singapore, and the appeal of the Malayan Communist Party. Ramakrishna worked too hard to locate communists lurking in the shadows or openly frolicking with noncommunists. He also worked too hard to capture the meaning of the past from the perspective of the present. Maintaining that Singapore's contemporary prosperity and the communist bloc's demise vindicate Coldstore, his narrative risks being mistaken for patriotic homily rather than an honest attempt to discover what, why, and how it happened.

Finally, Ramakrishna appears boxed in by the debate he wishes to transcend. Whether or not Coldstore was a political or security operation is a false dilemma. Since coming to power, Lee and members of his political party have consistently styled themselves as Singapore's indispensable leaders. They maintain that without their leadership or resolve, the city-state would sink, dragging themselves and citizens down with it. Politicians entertaining such thoughts are unlikely to overlook challenges to their power and the domains they control. It seems reasonable to suggest that an inclusive interpretation of Coldstore has more explanatory power and scope than the exclusive political or security thesis. 
The reservations aside, Ramakrishna, as well as Comber, should be congratulated for producing two stimulating books. Both, in advancing spirited arguments and challenging alternative explanations, do justice to a professional discipline dedicated to lively debates about the past. Both, in grounding their studies in new sources, also bring into sharp focus the possibilities for new interpretations of history. The two books will provoke other scholars to reexamine the postwar history of Malaya and Singapore. And that is a good thing. 